\title{
Effect of Different Priming Methods and Durations for Kabuli Chickpea (Cicer arietinum L.) Seeds
}

\author{
Rupesh Kumar* and Prashant Kumar Rai
}

Department of Genetics and Plant Breeding, Naini Agricultural Institute, Sam Higginbottom University of Agriculture, Technology and Sciences, Prayagraj, 211007 U.P., India

*Corresponding author

\section{Keywords}

Chickpea (Cicer arietinum $\mathrm{L}$. kabuli, Priming and seedling parameters

\section{Article Info}

Accepted:

08 January 2020

Available Online:

10 February 2020

\section{A B S T R A C T}

The present study were carried out in the Laboratory and Field Experimentation Centre of Department of Genetics and Plant Breeding, Sam Higginbottom University of Agriculture, Technology and Sciences, Prayagraj (U.P.) during Rabi season 2015-16 and 2016-17 entitled Effect of different priming methods and durations for Kabuli Chickpea (Cicer arietinum L.) seeds in order to effect of different priming treatment and durations on growth, field emergence yield and yield components of the stored chickpea seeds (Cicer kabulium L.), this experiment was conducted by randomized block design (RBD) design with three replications viz., $\mathrm{T}_{0}$-Control (without dry any treatment), $\mathrm{T}_{1}$-Hydro priming (HP) with distilled water $12 \mathrm{hrs}, \mathrm{T}_{2}$-Osmopriming with poly ethylene glycol PEG 6000 (0.5 Mega Pascal) for $8 \mathrm{hrs}, \mathrm{T}_{3}$-Osmopriming with poly ethylene glycol PEG 6000 (0.5 Mega Pascal) for $10 \mathrm{hrs}, \mathrm{T}_{4}$-Osmopriming with poly ethylene glycol PEG 6000 (0.5 Mega Pascal) for $12 \mathrm{hrs}, \mathrm{T}_{5}$-Halopriming with $\mathrm{NaCl}(9 \%)$ for $8 \mathrm{hrs}, \mathrm{T}_{6}$-Halopriming with $\mathrm{NaCl}$ (9\%) for $10 \mathrm{hrs}, \mathrm{T}_{7}$-Halopriming with $\mathrm{NaCl}(9 \%)$ for $12 \mathrm{hrs}, \mathrm{T}_{8}$-Magnetic priming (50 Mili Tesla for 5minutes), $\mathrm{T}_{9}$-Magnetic priming (75MiliTesla for 5minutes), $\mathrm{T}_{10}$-Electric priming (0.5 Ampere for 5 minutes) and $\mathrm{T}_{11}$-Electric priming (1.0 Ampere for 5 minutes). It was found that all the priming methods showed significance difference with the control and the highest Field emergence (\%), Days to 50\% flowering, Plant height $(\mathrm{cm})$, Number of primary branches per plant, Days to maturity, Number of pods/plant, Number of seeds/pod, 100- seed weight (g), Biological yield (g), Harvest index (\%), Yield per plant (gm) and Seed yield per hectare $(\mathrm{q} / \mathrm{ha})$. The results showed that the germination and subsequent morphological parameters are statistically significant in Chickpea (Kabuli) seeds treated with Poly ethylene glycol 6000 [0.5\%] for 8 hours duration when compared with other treatments and untreated ones. This study showed that seed priming could improve some growth and yield parameters in kabuli chickpea seed priming, its simplicity no requirements for extensive equipment and chemicals could be used method for overcoming problems related to a poor germination and seedling character, growth and vigour and with the help of seed priming treatments which are cost effective, economic, non-toxic and from eco-friendly sources. 


\section{Introduction}

Chickpea (Cicer arietinum L.) is the third most important food legume grown in $11 \mathrm{mha}$ with 9 million ton production (http://apps.fao.org). It provides a high quality protein to the people in developing countries. People in the developed countries consider it as a health food. Green leaves / twigs of chickpea are used in preparing a nutritious vegetable in countries of South Asia. These are also used as high protein fodder mixed with cereal leaves. Chickpea stover is fed to the cattle/goats as a nutrient-rich supplement to their major cereal fodder in the lean season. Two main types are recognized. Desi type with small and brown seed accounts for nearly $90 \%$ and kabuli type with bold and cream-colored seed is grown in around 10\% area. Nearly, $90 \%$ of the crop is cultivated rainfed mostly on receding soil moisture and on marginal lands. If managed well, the crop could bring high returns to the farmer in addition to enhancing sustainability of agricultural systems.

Seed storage is preservation of seed with initial quality until it is needed for planting. The ability of seed to tolerate moisture loss allows the seed to maintain the viability in dry state. Storage starts in the mother plant itself when it attains physiological maturity. Low degrees of moisture and temperature are the two most important factors in storage of seeds. Both of these factors also reduce seed respiration and the growth of pests. Storage area should be easily accessible for loading and unloading operations. The storage area should be relatively moisture proof which is necessary for the maintenance of seed moisture content. The go-down should be clean and dry. Storage area should be termite and rodent proof. There should not be any cracks or holes in the wall and floor of the storage go-down.
Experimental study of the effects of electricity on plant growth began in 1746 . Early researchers discovered the application of electricity in agriculture for different purposes such as for seed treatment, seedling growth, plant growth, insect control and so on. Although their research aims were good, their apparatus, experimental designs and methods, process, dosage, amplitude of voltage, and the treatment time were not scientific so that they often got contradictory results. The application of electricity, magnetism, monochrome light and sound can stimulate the growth of plants to a great extent. The energies are applied to the seeds, plants, soil or the water and nutrients. This technology termed as electro culture, can protect plants from diseases, insects and frost. These methods can also reduce the requirements for fertilizer or pesticides. It is well known that currents of electricity exist in the atmosphere. Clouds are charged and discharged. There is constant change of electricity from earth to air and from air to earth. The earth is the reservoir for all electricity. The electricity is the potent factor in the economy of nature and has more to do with the growth and developments of plants. Plant food is carried throughout the plant by means of the flow of sap, these currents circulates through all rootlets and centre as it were, in the stalk, carrying their tiny burdens of various elements and depositing them in the proper places. This phenomenon of sap circulation can be doubled due to electricity. Electro-culture can protect plants from diseases, insects and frost. These methods also reduce the requirements for fertilizer or pesticides. Farmers can grow bigger and better crops in less time, with less effort and at a lower cost. Plant growth as well as the biological processes of seeds can be accelerated or inhibited by high intensity electric fields. The mechanism of these effects is still insufficiently known. Electrostatic treatment is assumed to enhance seed vigour 
by influencing the biochemical processes which involve free radicals, and by stimulating the activity of proteins and enzymes (Morar et al., 1999). Corona discharges also seem to affect the biological activity of seeds (Lynikiene 2006). Destruction of microorganisms in liquids by using high intensity electric fields has been thoroughly investigated by many scientists (Moon 2000, Kuzmanov 2010, Lynikiene 2003, Gui 2003). A review of the efforts on the inactivation of microorganisms by pulsed electric fields can be found in (Songnum, 2011). The electric fields effects were mainly attributed to the field-induced intensification of the biological processes in seeds.

\section{Materials and Methods}

The variety of Chickpea Kabuli [Ujjwal] were obtained from Indian Institute of Pulse Research [I.I.P.R], Kanpur, Uttar Pradesh and stored for one planting season. After storage, seeds were primed with different doses of Distill water, Polyethelene Glycol, Sodium Chloride, Magnetic and Electric doses. Treated seeds of Chickpea [Kabuli] were soaked in Randomized Block Design (RBD) in 03 replications for two seasons [Rabi] at Field Experimentation Centre, Department of Genetics and Plant Breeding and seed quality experiment were conducted in Post Graduate Laboratory, Department of Genetics and Plant Breeding and Laboratory of Physics, Department of Physics, Sam Higginbottom University of Agriculture, Technology \& Sciences, Prayagraj (U.P.)

\section{Results and Discussion}

\section{Analysis of variance}

The analysis of variance for different characters is presented in (Table 1 and 2). Mean performance of 12 characters viz., Field emergence (\%), Days to 50\% flowering, Plant height $(\mathrm{cm})$, Number of primary branches per plant, Days to maturity, Number of pods/plant, Number of seeds/pod, 100- seed weight (g), Biological yield (g), Harvest index $(\%)$, Yield per plant (gm) and Seed yield per hectare (q/ha) were subjected to analysis of variance for experimental design. Analysis of variance was carried out for 12 characters to partitioning the total variation in 2016-2017. The mean sum of squares due to treatments showed significant for the all characters under study at 5\% level of significance. Thus, indicate selection for different quantitative character for chickpea improvement.

\section{Mean performance}

Significant differences were observed on all the growth, field emergence yield and yield components chickpea variety (Ujjwal) due to treatments.Perusal from table that significantly maximum increase in field emergence occurs by $T_{2}$ [Osmopriming with poly ethylene glycol PEG 6000 (0.5 Mega Pascal) for $8 \mathrm{hrs}$ ] was $(88.86,89.67 \%)$ followed by $\mathrm{T}_{6}$ [Halopriming with $\mathrm{NaCl}(9 \%)$ for $10 \mathrm{hrs}$ ] was $(88.67,88.33$ while lowest field emergence $(82.33,83.37$ ) was observed with unprimed control treatment during the year 2017-018 respectively. In case of plant height $(\mathrm{cm})$ occurs by $\mathrm{T}_{2}$ [Osmopriming with poly ethylene glycol PEG 6000 (0.5 Mega Pascal) for $8 \mathrm{hrs}$ ] was $(41.10,42.05 \mathrm{~cm})$, while lowest plant height $(\mathrm{cm})(25.41,26.52$ $\mathrm{cm})$ was observed with unprimed control treatment during the year 2017-018, respectively. Perusal from table that significantly minimum in days to $50 \%$ flowering occurs by $\mathrm{T}_{2}$ [Osmopriming with poly ethylene glycol PEG 6000 (0.5 Mega Pascal) for $8 \mathrm{hrs}$ ] was $(79.00,78.33)$, while highest days to $50 \%$ flowering $(88.33,89.67)$ was observed with unprimed control. Significantly maximum increase in number of primary branches occurs by $\mathrm{T}_{2}$ [Osmopriming with poly ethylene glycol PEG 6000 (0.5 
Mega Pascal) for $8 \mathrm{hrs}$ ] was (4.56, 4.60), while lowest number of primary branches $(2.99,3.00)$ was observed with unprimed control. The minimum in days to maturity occurs by $\mathrm{T}_{2}$ [Osmopriming with poly ethylene glycol PEG 6000 (0.5 Mega Pascal) for $8 \mathrm{hrs}$ ] was $(146.00,145.67)$, while highestdays to maturity $(153.63,152.30)$ was observed with unprimed control. However the maximum increase in number of seed per pod occurs by $\mathrm{T}_{2}$ [Osmopriming with poly ethylene glycol PEG 6000 (0.5 Mega Pascal) for $8 \mathrm{hrs}$ ] was $(3.33,3.87)$ followed by $\mathrm{T}_{6}$ [Halopriming with $\mathrm{NaCl}(9 \%)$ for $10 \mathrm{hrs}$ ] was $(3.00,3.20)$ while lowest number of seed per pod $(1.72,1.87)$ was observed with unprimed control treatment during the year 2017-018 respectively. Significantly maximum increase in 100 seed weight $(\mathrm{gm})$ occurs by $\mathrm{T}_{2}$ [Osmopriming with poly ethylene glycol PEG 6000 (0.5 Mega Pascal) for $8 \mathrm{hrs}$ ] was (21.03, $21.11 \mathrm{~g}$ ), while lowest 100 seed weight (gm) $(16.28,18.10 \mathrm{~g})$ was observed with unprimed control. Similar the maximum biological yield (gm) occurs by $T_{2}$ [Osmopriming with poly ethylene glycol PEG 6000 (0.5 Mega Pascal) for $8 \mathrm{hrs}$ ] was $(16.21,16.30 \mathrm{~g})$, while lowest biological yield $(\mathrm{gm})(13.91,14.05 \mathrm{~g})$ was observed with unprimed control. Seed yield per plant (gm) was occurs by $\mathrm{T}_{2}$ [Osmopriming with poly ethylene glycol PEG 6000 (0.5 Mega Pascal) for $8 \mathrm{hrs}$ ] was (5.65, $5.68 \mathrm{~g}$ ), while lowest seed yield per plant (gm) $(4.85,4.89 \mathrm{~g})$. Similarly the maximum seed yield ( $\mathrm{q} / \mathrm{ha}$ ) observed by $\mathrm{T}_{2}$ [Osmopriming with poly ethylene glycol PEG 6000 (0.5 Mega Pascal) for $8 \mathrm{hrs}$ ] was $(18.87,19.24 \mathrm{q})$, while lowest seed yield (q/ha) $(16.27,16.10 \mathrm{q})$ was observed with unprimed control. As that of harvest index (\%) occurs by $\mathrm{T}_{5}$ [Halopriming with $\mathrm{NaCl}(9 \%)$ for $8 \mathrm{hrs}$ ] was (35.64\%) in first year, while $\mathrm{T}_{10}$ [Electric priming (0.5 Ampere for 5 minutes)] was $(35.40 \%)$ in second year and pooled data was $\mathrm{T}_{5}$ [Halopriming with $\mathrm{NaCl}(9 \%)$ for $8 \mathrm{hrs}$ ], while lowest harvest index (\%) $(34.7934 .80$ $\%$ ) was observed with unprimed control treatment during the year 2017-018 respectively.

Table.1 Analysis of variance for 12 different quantitative characters of chickpea variety Ujjwal

\begin{tabular}{|c|c|c|c|c|c|c|}
\hline \multirow[t]{2}{*}{ Parameters } & \multicolumn{3}{|c|}{ 2016-17 } & \multicolumn{3}{|c|}{ 2017-18 } \\
\hline & $\begin{array}{c}\text { Due to } \\
\text { repli } \\
\mathrm{df}=2\end{array}$ & $\begin{array}{l}\text { Due to treat } \\
\qquad \mathrm{df}=11\end{array}$ & $\begin{array}{c}\text { Due to } \\
\text { error } \\
\mathrm{df}=35\end{array}$ & $\begin{array}{l}\text { Due to } \\
\text { replidf }=2\end{array}$ & $\begin{array}{l}\text { Due to treat } \\
\qquad \mathrm{df}=11\end{array}$ & $\begin{array}{c}\text { Due to } \\
\text { error } \\
\mathrm{df}=35\end{array}$ \\
\hline \multicolumn{7}{|l|}{ Ujjwal } \\
\hline Field emergence & 4241.479 & $2983.011 * *$ & 115.365 & 17044.33 & $3815.60 * *$ & 330.57 \\
\hline Days to $50 \%$ flowering & 8.361 & $2901.172 * *$ & 1.513 & 66.778 & $3086.270 * *$ & 3.475 \\
\hline Plant height & 1.294 & $465.76^{* *}$ & 1.062 & 1.472 & $495.74 * *$ & 0.841 \\
\hline Number of primary branches/ plant & 0.203 & $6.435 *$ & 0.086 & 0.160 & $0.407 *$ & 0.124 \\
\hline Days to maturity & 1.00 & $6668.174 * *$ & 0.455 & 0.028 & $6623.156^{* *}$ & 0.119 \\
\hline Number of pods/plant & 78.593 & $1529.959 * *$ & 118.628 & 136.223 & $3720.452 * *$ & 201.062 \\
\hline Number of seeds/pod & 0.021 & $3.957 *$ & 0.019 & 0.003 & $2.200 *$ & 0.013 \\
\hline 100- seed weight & 0.471 & $5599.770 * *$ & 0.778 & 0.206 & $621.578 * *$ & 0.449 \\
\hline Biological yield & 0.072 & $1.990 *$ & 0.078 & 0.711 & $156.664 * *$ & 0.976 \\
\hline Harvest index & 0.333 & $14.216^{* *}$ & 0.152 & 0.075 & $11.955^{* *}$ & 0.386 \\
\hline Yield per plant & 2.048 & $111.507 * *$ & 2.940 & 5.964 & $53.958 * *$ & 3.324 \\
\hline Seed yield per hectare & 0.235 & $1.455^{*}$ & 0.092 & 0.563 & $1.471 *$ & 0.163 \\
\hline
\end{tabular}


Table.1a Mean performance of field emergence, growth characters of chickpea Ujjwal

\begin{tabular}{|c|c|c|c|c|c|c|c|c|c|c|c|c|c|c|}
\hline \multirow[t]{2}{*}{ Treatments } & \multicolumn{2}{|c|}{$\begin{array}{c}\text { Field } \\
\text { emergence } \\
(\%)\end{array}$} & \multicolumn{2}{|c|}{$\begin{array}{l}\text { Plant height } \\
\text { (cm) }\end{array}$} & \multicolumn{2}{|c|}{$\begin{array}{l}\text { Days to } 50 \% \\
\text { flowering }\end{array}$} & \multicolumn{2}{|c|}{$\begin{array}{c}\text { Number of } \\
\text { primary } \\
\text { branches }(\%)\end{array}$} & \multicolumn{2}{|c|}{$\begin{array}{l}\text { Days to maturity } \\
(\%)\end{array}$} & \multicolumn{2}{|c|}{$\begin{array}{l}\text { Number of } \\
\text { seed per pod }\end{array}$} & \multicolumn{2}{|c|}{$\begin{array}{c}100 \text { seed } \\
\text { weight }(\mathrm{gm})\end{array}$} \\
\hline & 1 st yr & 2nd yr & $1 \mathrm{st} y \mathrm{r}$ & 2nd yr & $1 \mathrm{st} y r$ & 2nd yr & $1 \mathrm{st} \mathrm{yr}$ & 2nd yr & $1 \mathrm{st} y \mathrm{r}$ & 2nd yr & $1 \mathrm{st} y r$ & 2nd yr & $1 \mathrm{st} y r$ & 2nd yr \\
\hline $\mathbf{T}_{\mathbf{0}}$ & 81.99 & 82.66 & 39.49 & 40.84 & 89.33 & 90.00 & 4.00 & 4.05 & 114.63 & 113.30 & 1.87 & 1.99 & 23.28 & 25.25 \\
\hline $\mathbf{T}_{1}$ & 82.33 & 82.67 & 41.14 & 43.13 & 87.66 & 88.33 & 4.10 & 4.15 & 108.60 & 108.27 & 2.81 & 2.42 & 24.42 & 26.39 \\
\hline $\mathbf{T}_{2}$ & 88.67 & 89.00 & 53.80 & 53.86 & 69.00 & 79.66 & 6.01 & 6.15 & 107.00 & 106.34 & 4.28 & 4.33 & 28.01 & 29.87 \\
\hline $\mathbf{T}_{\mathbf{3}}$ & 84.67 & 84.33 & 46.49 & 47.88 & 82.33 & 83.66 & 5.80 & 5.91 & 110.30 & 108.97 & 2.95 & 3.42 & 26.74 & 28.71 \\
\hline $\mathbf{T}_{4}$ & 83.67 & 83.97 & 46.55 & 47.74 & 82.00 & 83.00 & 5.13 & 5.60 & 111.63 & 110.30 & 2.33 & 3.60 & 24.10 & 27.10 \\
\hline $\mathbf{T}_{5}$ & 84.00 & 82.99 & 45.50 & 46.73 & 83.33 & 84.00 & 5.26 & 5.36 & 110.30 & 109.63 & 3.52 & 3.13 & 25.53 & 27.50 \\
\hline $\mathbf{T}_{6}$ & 87.33 & 88.55 & 50.47 & 50.86 & 74.99 & 75.90 & 5.93 & 6.05 & 107.63 & 106.30 & 3.95 & 3.90 & 27.67 & 29.67 \\
\hline $\mathbf{T}_{7}$ & 84.10 & 84.33 & 47.29 & 48.48 & 89.00 & 88.33 & 5.59 & 5.67 & 111.97 & 110.64 & 2.77 & 2.67 & 25.10 & 27.07 \\
\hline $\mathbf{T}_{8}$ & 83.45 & 83.66 & 47.31 & 48.70 & 82.00 & 82.33 & 5.87 & 5.92 & 109.60 & 108.27 & 2.99 & 3.09 & 27.25 & 27.15 \\
\hline $\mathbf{T}_{9}$ & 86.67 & 86.85 & 48.55 & 49.89 & 81.00 & 80.66 & 5.90 & 6.00 & 109.33 & 108.00 & 3.75 & 3.67 & 27.45 & 29.33 \\
\hline$T_{10}$ & 83.23 & 82.99 & 44.96 & 46.35 & 87.00 & 88.00 & 4.09 & 4.29 & 111.97 & 110.33 & 2.94 & 2.54 & 24.57 & 26.54 \\
\hline $\mathrm{T}_{11}$ & 82.93 & 82.69 & 44.96 & 46.35 & 86.00 & 86.33 & 5.06 & 5.27 & 110.63 & 109.30 & 2.88 & 2.61 & 24.75 & 26.72 \\
\hline F- test & $\mathrm{S}$ & $\mathrm{S}$ & S & $\mathrm{S}$ & $\mathrm{S}$ & S & $\mathrm{S}$ & $\mathrm{S}$ & $\mathrm{S}$ & $\mathrm{S}$ & $\mathrm{S}$ & S & $\mathrm{S}$ & $\mathrm{S}$ \\
\hline S. Ed. ( $( \pm)$ & 1.23 & 2.305 & 1.592 & 1.499 & 1.004 & 1.522 & 0.239 & 0.287 & 0.55 & 0.281 & 0.113 & 0.093 & 0.724 & 0.577 \\
\hline $\begin{array}{l}\text { C. D. }(P= \\
0.05)\end{array}$ & 2.435 & 4.564 & 3.168 & 2.983 & 2.073 & 3.141 & 0.494 & 0.593 & 1.136 & 0.581 & 0.232 & 0.192 & 1.494 & 1.19 \\
\hline
\end{tabular}

Legends: $\mathrm{T}_{0}-$ Control, $\mathrm{T}_{1}$ - Hydro priming (HP) with distilled water $12 \mathrm{hrs}, \mathrm{T}_{2}$ - Osmopriming with poly ethylene glycol PEG 6000 (0.5 Mega Pascal) for 8 hrs, $\mathrm{T}_{3}$. Osmopriming with poly ethylene glycol PEG 6000 ( 0.5 Mega Pascal) for $10 \mathrm{hrs}, \mathrm{T}_{4}$. Osmopriming with poly ethylene glycol PEG 6000 ( 0.5 Mega Pascal) for 12 hrs, $\mathrm{T}_{5}$. Halopriming with $\mathrm{NaCl}(9 \%)$ for $8 \mathrm{hrs}, \mathrm{T}_{6}$. Halopriming with $\mathrm{NaCl}(9 \%)$ for $10 \mathrm{hrs}, \mathrm{T}_{7}$. Halopriming with $\mathrm{NaCl}$ (9\%) for 12 hrs, $\mathrm{T}_{8}$. Magnetic priming (50Mili Tesla for 5minutes), $\mathrm{T}_{9}$. Magnetic priming (75Mili Tesla for 5 minutes), $\mathrm{T}_{10}$. Electric priming ( 0.5 Ampere for 5 minutes), $\mathrm{T}_{11}$ - Electric priming (1.0 Ampere for minutes), $\mathrm{F}$ - test, S. Ed. ( \pm ) - Standard Error of difference ( \pm ), C. D. $(\mathrm{P}=0.05)$ - Critical Difference, C.V.- Coefficient of variation (\%)-Percentage, $(\mathrm{cm})-$ Centimeter, g- Gram. 
Table.2b Mean performance of yield and yield characters of Chickpea Ujjwal

\begin{tabular}{|c|c|c|c|c|c|c|c|c|}
\hline \multirow[t]{2}{*}{ Treatments } & \multicolumn{2}{|c|}{$\begin{array}{l}\text { Biological yield } \\
(\mathrm{gm})\end{array}$} & \multicolumn{2}{|c|}{$\begin{array}{l}\text { Seed yield per } \\
\text { plant (gm) }\end{array}$} & \multicolumn{2}{|c|}{ Seed yield (q/ha) } & \multicolumn{2}{|c|}{ Harvest index (\%) } \\
\hline & 1 st yr & 2nd yr & 1 st yr & $2 \mathrm{nd} y \mathrm{r}$ & $1 \mathrm{st} y r$ & 2nd yr & $1 \mathrm{st} \mathrm{yr}$ & 2nd yr \\
\hline $\mathbf{T}_{\mathbf{0}}$ & 21.46 & 21.54 & 7.47 & 7.49 & 16.56 & 16.62 & 53.70 & 53.31 \\
\hline $\mathbf{T}_{1}$ & 21.54 & 21.69 & 7.38 & 7.55 & 16.62 & 16.73 & 47.37 & 48.03 \\
\hline $\mathbf{T}_{2}$ & 24.48 & 24.57 & 8.53 & 8.58 & 18.89 & 18.96 & 52.62 & 52.64 \\
\hline $\mathbf{T}_{3}$ & 22.61 & 22.64 & 7.84 & 7.89 & 17.44 & 17.47 & 52.06 & 51.87 \\
\hline $\mathbf{T}_{4}$ & 22.29 & 22.69 & 7.64 & 7.79 & 17.20 & 17.51 & 52.33 & 52.81 \\
\hline $\mathbf{T}_{5}$ & 22.72 & 22.90 & 7.88 & 7.99 & 17.53 & 17.67 & 55.61 & 55.84 \\
\hline $\mathbf{T}_{6}$ & 23.96 & 24.11 & 8.35 & 8.41 & 18.49 & 18.60 & 52.25 & 52.04 \\
\hline $\mathbf{T}_{7}$ & 22.35 & 22.52 & 7.68 & 7.86 & 17.24 & 17.38 & 49.93 & 50.64 \\
\hline $\mathbf{T}_{8}$ & 22.67 & 22.64 & 7.89 & 7.88 & 17.49 & 17.47 & 51.98 & 51.34 \\
\hline $\mathbf{T}_{9}$ & 23.64 & 23.82 & 8.26 & 8.34 & 18.24 & 18.38 & 52.71 & 52.65 \\
\hline $\mathbf{T}_{10}$ & 23.18 & 23.39 & 8.09 & 8.15 & 17.89 & 18.04 & 55.07 & 54.96 \\
\hline $\mathbf{T}_{11}$ & 22.95 & 23.30 & 7.99 & 8.12 & 17.71 & 17.98 & 51.19 & 51.56 \\
\hline F- test & $\mathrm{S}$ & $\mathrm{S}$ & $\mathrm{S}$ & $\mathrm{S}$ & $\mathrm{S}$ & $\mathrm{S}$ & $\mathrm{S}$ & $\mathrm{S}$ \\
\hline S. Ed. $( \pm)$ & 0.229 & 0.807 & 0.41 & 0.499 & 0.248 & 0.33 & 0.318 & 0.508 \\
\hline $\begin{array}{l}\text { C. D. }(P= \\
0.05)\end{array}$ & 0.472 & 1.665 & 0.816 & 0.993 & 0.512 & 0.681 & 0.656 & 1.048 \\
\hline
\end{tabular}

Legends: $\mathrm{T}_{0}$ - Control, $\mathrm{T}_{1}$ - Hydro priming (HP) with distilled water $12 \mathrm{hrs}, \mathrm{T}_{2}$ - Osmopriming with poly ethylene glycol PEG 6000 (0.5 Mega Pascal) for $8 \mathrm{hrs}, \mathrm{T}_{3}$. Osmopriming with poly ethylene glycol PEG 6000 (0.5 Mega Pascal) for $10 \mathrm{hrs}, \mathrm{T}_{4}$ - Osmopriming with poly ethylene glycol PEG 6000 (0.5 Mega Pascal) for $12 \mathrm{hrs}, \mathrm{T}_{5}$ Halopriming with $\mathrm{NaCl}(9 \%)$ for $8 \mathrm{hrs}, \mathrm{T}_{6}$. Halopriming with $\mathrm{NaCl}(9 \%)$ for $10 \mathrm{hrs}, \mathrm{T}_{7}$. Halopriming with $\mathrm{NaCl}$ (9\%) for $12 \mathrm{hrs}, \mathrm{T}_{8}$. Magnetic priming (50Mili Tesla for 5minutes), $\mathrm{T}_{9}$. Magnetic priming (75Mili Tesla for 5minutes), $\mathrm{T}_{10}$ - Electric priming (0.5 Ampere for 5 minutes), $\mathrm{T}_{11}$. Electric priming (1.0 Ampere for minutes), $\mathrm{F}-$ test, S. Ed. $( \pm)$ - Standard Error of difference $( \pm)$, C. D. $(\mathrm{P}=0.05)$ - Critical Difference, C.V.- Coefficient of variation (\%)-Percentage, $(\mathrm{cm})$ - Centimeter, g- Gram

The similar trend showed that all the treatments recorded significantly maximum observed by $\mathrm{T}_{2}$ [Osmopriming with poly ethylene glycol PEG 6000 (0.5 Mega Pascal) for $8 \mathrm{hrs}$ ] in chickpea variety Ujjwal.

This study revealed that PEG treatments caused partial increases in the germination percentage compared to the control (with the exception of the germination percentage). PEG application provided a slight advantage to the germination percentage in cultivar Ujjwal. The priming media affected the germination percentage of the chickpea varieties in different ways. The different response of the varieties to different priming media was previously reported by Giri and Schillinger (2003). Several osmotica, such as PEG, have been shown to have positive effects on germination capability (Dell-Aquila and Taranto, 1986; Lemrasky and Husseini, 2012). The positive effect of PEG application on increased germination percentage might be explained by an increase in the activity of key enzymes, such as amylase and proteases (Dell-Aquila and Tritto, 1990), which play an important role in the growth and development of the seed embryo. Indeed, these results are in agreement with Yari et al., (2010), who reported that seeds soaked in PEG-6000 had better germination performance, possibly due to low osmotic potential of the solution or to 
long priming duration. Lemrasky and Hosseini (2012) reported that the maximum seed germination percentage was obtained when the seed was primed with $10 \%$ PEG for $45 \mathrm{~h}$, and the rate of germination was improved when the seed was soaked in water and 10\% PEG. Dell-Aquila et al., (1984) indicated a relationship between the pattern of water absorption, the reactivation of mitotic activity, and the start and synchronization of germination upon the correct application of osmopriming treatment. In addition, it has been reported that PEG application activates several compounds that promote germination (Jie et al., 2002). These results are in accordance with the findings of Yari et al., (2010), who observed maximum seedling growth rate for both chickpea cultivars in seeds treated with $\mathrm{NaCl}$, when taken together, the results show that hydropriming treatment was comparatively superior in seedling growth rate among all priming applications. These findings are in agreement with previous reports (Ahmadi et al., 2007; GhassemiGolezaniki et al., 2008a). Several researchers reported the positive effect of hydropriming on seedling emergence rate, seedling establishment, early vigor, and the faster development of the seedling (Kibite and Harker, 1991). Priming with PEG-6000 resulted in the highest number of plants per square meter at late sowing in chickpea Ujjwal variety. Thus, seed priming with PEG appears to have promoted stand establishment at late sowing under field conditions.

Number of primary branches is an important component of grain yield and was found to be higher in DCP-92-3 seeds primed with $\mathrm{NaCl}$ and Ujwwal seeds primed with PEG at timely sowing. Jafar et al., (2012) concluded that maximum number of primary branches was observed from osmopriming and hydropriming treatments in chickpea. Thus, our results were in agreement with these previous results. There are reports that hydration of seeds that equals, but does not exceed, the lag phase of priming permits early DNA replication, increased RNA and protein synthesis, greater ATP availability, faster embryo growth, repair of deteriorated seed parts (Karssen et al., 1989; Saha et al., 1990), and reduced leakage of metabolites (Styer and Cantliffe, 1983) than checks (Giri and Schillinger, 2003).

For both varieties and sowing times, PEG and $\mathrm{NaCl}$ seed priming applications increased grain yield. This may be a result of seed priming causing biochemical changes in the structure of the seeds, such as activation of enzymes related to germination and stand establishment. Jafar et al., (2012) reported that osmopriming seeds (with $\mathrm{NaCl}$ ) followed by ascorbate priming treatments also enhanced protease and $\alpha$-amylase activities, which in turn helped to improve carbohydrate metabolism, leading to better assimilate translocation. All these factors might explain the higher grain yield in treatment compared to control conditions. However, Giri and Schillinger (2003) reported that none of the chickpea seed priming media benefited field emergence or subsequent grain yield in any of the cultivars compared to the controls. In summation, among the different priming agents used in the study, PEG priming on chickpea seeds was the most effective application for promoting seed germination, stand establishment, and grain yield under unfavorable sowing conditions such as late sowing. Seedling growth rate was also enhanced by priming seeds with water. Thus, PEG and hydropriming treatments are simple, cheap, and effective methods to improve seed germination and seedling growth in field conditions.

\section{References}

Abdul-Baki AA, Alderson JD (1973) Vigor determinations in soybean seed multiple 
criteria. Crop Science, 13; 630-633

Ahmadi A, Sio-Se Mardeh A, Poustini K, Esmailpour Jahromi M (2007). Influence of osmo and hydro priming on seed germination and seedling growth in wheat (Triticum aestivum L.) cultivars under different moisture and temperature conditions. Pak J Biol Sci 10: 4043-4049.

Baki and Anderson [1973]. Vigour Detemination in soyabean seed by multiple Criteria .crop science, 13,630633

Dell'Aquila A, Pignone D, Carella G (1984). Polyethylene glycol 6000 priming effects on germination of aged wheat seed lots. Biol Plantarum 26: 166-173.

Dell'Aquila A, Taranto G (1986). Cell division and DNA synthesis during osmopriming treatment and following germination aged wheat embryos. Seed Sci and Tech 14: 333-341.

Dell'Aquila A, Tritto V (1990). Ageing and osmotic priming in wheat seeds: effects upon certain components of seed quality. Ann Bot 65: 21-26.

Ghassemi-Golezani K, Aliloo AA, Valizadeh M, Moghaddam M (2008a). Effects of different priming techniques on seed invigoration and seedling establishment of lentil (Lens culinarisMedik.). J Food Agric Environ 6: 222-226.

Ghassemi-Golezani K, Aliloo AA, Valizadeh M, Moghaddam M (2008b). Effects of hydro and osmo-priming on seed germination and field emergence of lentil (Lens culinaris Medik.). Not Bot HortiAgrobo 36: 29-33.

Ghassemi-Golezaniki et al., 2008a, Effects of Hydro and Osmo-Priming on Seed Germination and Field Emergence of Lentil (Lens culinaris Medik.). Not. Bot. Hort. Agrobot. Cluj 36 (1), 29-33.

Giri GS, Schillinger WF (2003). Seed priming winter wheat for germination, emergence and yield. Crop Sci 43: 2135-2141.

Jafar MZ, Farooq M, Cheema MA, Afzal I, Basra SMA, Wahid MA, Aziz T, Shahid M (2012). Improving the performance of wheat by seed priming under saline conditions. J Agron Crop Sci 198: 38-45.

Jie LL, Ong S, Dong MO, Fang L, Hua EW (2002). Effect of PEG on germination and active oxygen metabolism in wild rye (Leymus chinensis) seeds. ActaPrat Sin 11: 59-64.

Karssen CM, Haigh A, Van der Toom P, Weges R (1989). Physiological mechanisms involved in seed priming. In: Taylorson RB, editor. Recent Advances in the Development and Germination of Seeds. New York, NY, USA: Plenum Press, pp. 269-280.

Yari et al. (2010), Effect of Seed Priming Duration and Temperature On Seed Germination Behavior of Bread Wheat (Triticum aestivum L.). ARPN Journal of Agricultural and Biological Science, (5): 1,1 to 6 .

\section{How to cite this article:}

Rupesh Kumar and Prashant Kumar Rai. 2020. Standardization of Different Priming Methods and Durations for Chickpea (Cicer arietinum L.) Seeds. Int.J.Curr.Microbiol.App.Sci. 9(02): 532-539. doi: https://doi.org/10.20546/ijcmas.2020.902.066 